\title{
A review of systematic approach for sustainable redevelopment of a closed landfill site
}

\begin{abstract}
Landfills are the common method of waste disposal. A closed landfill site can be an eyesore land and cause environmental hazardous impacts on surrounding areas. A sustainable solution for redevelopment of a closed landfill site, returns the land to an attractive and beneficial after-use. This study aim to identify potential sustainable solutions and factors in the redevelopment of closed landfill sites. The paper critically reviews the literature regarding vital understanding of the redevelopment process. The study also analyzed the successful landfill redevelopment projects in a wide range of time and locations to suggest the best enduse option. Additionally, the study offers an approach for integrating the social, economic and environmental benefits through the sustainable redevelopment solution contributing to the universal sustainable development and green built environment.
\end{abstract}

Keyword: Sustainable development; Closed landfill redevelopment; Landfill after-use 
